\title{
Kebijakan Dividen dari Perspektive Agency Cost Model (Studi Kasus Perusahaan yang Terdaftar di Bursa Efek Indonesia periode 2011-2013)
}

\author{
Akhmad Hitten* \\ Universitas Tanjungpura
}

\begin{abstract}
The paper examines the influence of agency theory on dividend policies with free cash flow, maturity, capital structure, and ownership dividend variables. The sample used in this research is Indonesian listed companies with observation period from 2010 to 2013, and the data collection technique used is data pooling or merging data. The data is analyzed with multiple linear regression analysis in SPSS program. The result of this study indicates that free cash flow, maturity, and ownership structure do not influence devidend policies, however capital structure influences dividend policies in Indonesian listed companies. The research also implies that agency cost theory, as the main model of relevance dividend preposition, cannot explain dividend policies in Indonesian Companies. The investors cannot rely solely on dividend policies in term of investment decisions in the future.
\end{abstract}

Keywords: Agency Cost Model With Free Cash Flow, Maturity, Capital Structure, Ownership Structure and Dividend Policies

\section{PENDAHULUAN}

Kebijakan dividen telah lama menjadi isu yang menarik dalam literatur finansial. Kebijakan dividen merupakan keputusan terpenting perusahaan. Oleh karena itu, studistudi baik kajian teoritis maupun empiris tentang kebijakan dividen masih sering diperdebatkan. Perdebatan tersebut bermula dari adanya dua proposisi yang saling kontroversi tentang relevansi dividen terhadap nilai perusahaan, yaitu disatu pihak irrelevance of dividend proposition dari Miller dan Modigliani (1961) dan lain pihak relevance of dividend proposition yang dimotori oleh Gordon dan Lintner dalam Brigham \& Houston (2010). Dalam perkembanganya, relevance of dividen proposition banyak menghasilkan model-model eksplanasi yang melandasi kajian-kajian empiris kebijakan dividen, diantaranya adalah signaling model dan agency cost model yang merupakan model utama yang dikembangkan berdasarkan asumsi asymetritric information.

\footnotetext{
* Korespondensi: Akhmad Hitten, Departemen Akuntansi, Fakultas Ekonomi dan Bisnis, Universitas Tanjungpura, Jalan Prof. DR. H. Hadari Nawawi, Pontianak 78124, Indonesia. Email: akhmad.hitten@ekonomi.untan.ac.id
} 
Signaling model yang dikembangkan pertama kali oleh Bhattacharya (1979) mengatakan bahwa dividen digunakan oleh manajer untuk memberikan sinyal tentang prospek kinerja perusahaan. Oleh karena itu kenaikan/penurunan dividen dianggap memiliki muatan informasi tentang prospek positif/negatif dari kinerja perusahaan. Atas dasar ini pasar akan mereaksi positif/negatif terhadap kenaikan/penurunan dividen.

Sedangkan agency cost model yang dikembangkan oleh Jensen \& Meckling (1976) menjelaskan bahwa dividen berfungsi sebagai salah satu sarana monitoring perilaku manajemen dan karenanya berperan meminimalkan agency cost yang timbul dari potensi conflict of interest antara pemegang saham (pemilik perusahaan) dan manajemen. Fokus kajian dari penelitian ini adalah salah satu bentuk dari kebijakan dividen, yaitu kebijakan dividen dari perspektif agency cost model.

Menurut Sartono (2000), kebijakan dividen adalah kebijakan atau keputusan apakah laba yang diperoleh perusahaan dibagikan kepada pemegang saham sebagai dividen atau ditahan dengan bentuk laba ditahan guna membiayai investasi. Ketika memutuskan berapa banyak laba yang harus didistribusikan kepada para pemegang saham, manager keuangan harus memperhatikan bahwa sasaran perusahaan adalah memaksimumkan nilai perusahaan, sehingga target rasio pembayaran sebaiknya berdasarkan pada preferensi investor untuk dividen versus capital gain, artinya keputusan pembagian dividen perlu dipertimbangkan kelangsungan hidup dan pertumbuhan perusahaan.

Berkaitan dengan kebijakan pembayaran dividen dalam kontek manajemen keuangan terlihat bahwa terdapat beberapa aspek yang saling berbeda kepentingan, yaitu antara kepentingan pihak pemegang saham, manajer, dan pihak perusahaan itu sendiri. Manajer direkrut perusahaan guna menjalankan tujuan pemegang saham yaitu memaksimalkan nilai perusahaan. Yang menjadi pertanyaan adalah apakah manajer akan bertindak konsisten dengan tujuan memakmurkan pemegang saham yaitu tujuan yang dibebankan pemegang saham kepada manajer? Sebab selain memenuhi tujuan pemegang ssaham, manajer juga pasti memiliki tujuan sendiri yang bukan tidak mungkin bisa bertentangan dengan tujuan pemegang saham (Brigham dan Houton, 2010).

Eksplanasi terhadap pembayaran dividen ada kemungkinan lain sebagai alternatif dari eksplanasi signaling model bahwa sebenarnya perusahaan memutuskan untuk membayar dividen bukan karena adanya prospek kinerja perusahaan yang baik ke depan, melainkan karena perusahaan mengalami kelebihan kas (free cash flow) dari yang diperlukan. Kelebihan kas ini jika tidak didistribusikan kepada pemegang saham akan mendorong manajemen untuk memanfaatkan ke dalam proyek-proyek yang tidak efisien (tidak profitable), suatu tindakan manajemen yang dianggap tidak sejalan dengan kepentingan pemegang saham. Argumen ini pertama kali dilontarkan oleh Jensen (1986) yang disebut dengan free cash flow hypothesis yang merupakan bagian dari eksplanasi 
agency cost model.

Sejalan dengan free cash flow hypothesis ini, Grullon, Rony dan Bhaskaran (2002) juga mengemukakan bahwa perusahaan membayar atau menaikkan dividen lebih disebabkan mereka sudah memasuki fase kedewasaan (maturity). Perusahaan yang memasuki fase ini tidak lagi membutuhkan dana untuk membiayai proyek-proyek investasi yang dianggap menguntungkan sehingga dana yang tidak dimanfaatkan untuk investasi sebaiknya didistribusikan kepada pemegang saham. Argumen ini dikenal sebagai maturity atau overinvestment hypothesis dan terbukti kebenarannya dalam menjelaskan perilaku kebijakan dividen di lingkungan perusahaan go-public di Amerika (Sharma, 2001; Jain, Shekhar, dan Torbey, 2003).

Penelitian-penelitian yang ada sebelumnya dengan basis data pasar modal di Amerika (Sharma, 2001; Jain et al., 2003; Bullan; Subramanian dan Tanlu, 2003) menunjukkan perusahaan-perusahaan yang memutuskan untuk melakukan pembayaran dividen terbukti memasuki fase kedewasaan (maturity) mereka. Namun temuan ini perlu diklarifikasi dalam konteks yang berbeda seperti konteks pasar modal di Indonesia. Hal ini penting mengingat perilaku kebijakan dividen di lingkungan perusahaan go-public di Indonesia sebagaimana telah dijelaskan sebelumnya, sangat berbeda bahkan bertolak belakang dengan perusahaan-perusahaan go-public di Amerika dari sisi timing dividen.

Agency cost Model yang dikembangkan oleh Jensen dan Meckling (1976), bahwa kebijakan dividen digunakan untuk meminimalisasi agency cost yang timbul dari potensi conflict of interest antara agen (manajer) dengan principal (pemegang saham) akibat adanya pemisahan diantara kedua belah pihak tersebut. Agency cost merupakan biaya yang timbul dalam rangka mengendalikan atau mengawasi tindakan manajer agar sesuai kepentingan principal.

Yang menjadi pertanyaan fundamental peneliti ini dari perspektif agency cost theory, salah satu model eksplanasi utama kebijakan dividen yang berbasis pada relevansi of dividend proposition, yaitu apakah perilaku kebijakan dividen di lingkungan perusahaan-perusahaan go publik di Indonesia memiliki relevansi dengan mekanisme monitoring oleh pemegang saham terhadap manajemen sebagaimana dicerminkan pada struktur kepemilikan, struktur modal, free cash flow, fase kedewasaan (maturity).

Jensen dan Meckling (1976) menyatakan konflik kepentingan antara manajemen (agen) dan pemegang saham dapat diminimalkan dengan suatu mekanisme pengawasan yang dapat mensejajarkan kepentingan-kepentingan tersebut. Dampak dari adanya mekanisme pengawasan akan menimbulkan biaya yang disebut sebagai biaya keagenan (agency cost). Selanjutnya Easterbrook (1984), dikutip oleh Noronha, Shome, and Morgan (1996), menyatakan bahwa efektifitas dividen sebagai alat monitoring bergantung kepada keberadaan sarana-sarana monitoring lainnya, misal kepemilikan manajerial dan struktur modal. 
Jensen \& Meckling (1976) mengemukakan bahwa agency cost akan rendah dalam perusahaan dengan kepemilikan manajerial (managerial ownership) yang tinggi, ini dimungkinkan dengan adanya penyatuan antara kepentingan pemegang saham dengan kepentingan manajer yang dalam hal ini berfungsi segbagai agent dan sekaligus sebagai principal. Hal yang sama bisa terjadi di perusahaan dimana leage block shareholder (pemegang saham dalam jumlah besar) yang biasanya terdiri dari pemegang saham institusi (institutional shareholder) yang memiliki kemampuan tinggi untuk mengendalikan manajer (Frankfurter \& Wood, 1994).

Pada aspek lain, sturuktur modal, dari agency cost model, perusahaan yang struktur modalnya lebih banyak melibatkan modal asing (dari kreditur), maka pengawasan akan lebih intensif dari kreditur terhadap manajemen, sehingga ketergantungan terhadap dividen sebagai sarana monitoring makin kecil dibanding dengan perusahaan dengan sruktur modal yang rendah.

Penelitian yang dilakukan oleh Crutchley dan Hansen (1999), Putri dan Nasir (2006), Amidu dan Abor (2006), Sisca (2008) menghasikan bukti hasil empiris bahwa variabel kepemilikan institusional mempunyai arah negatif dan berpengaruh signifikan terhadap kebijakan dividen. Beda halnya yang dilakukan oleh Sunarto (2004) dan Sugeng (2009) bahwa variabel struktur kepemilikan institusional secara signifikan tidak berpengaruh terhadap kebijakan dividen namun punya arah negatif. Hasil penelitian Sunarto (2004) menujukkan bahwa variabel struktur modal tidak berpengaruh dengan arah negatif sedangkan Sugeng (2009) berkesimpulan bahwa variabel struktur modal berpengaruh signifikan dengan arah positif. Dalam konteks agency cost model, pertanyaan yang perlu dikemukakan adalah apakah struktur kepemilikan dan struktur

modal di lingkungan perusahaan-perusahaan di Indonesia ikut berperan terhadap kebijakan dividen?

\section{TINJAUAN PUSTAKA}

\subsection{Kebijkan dividen}

Kebijakan adalah hal-hal atau faktor-faktor yang perlu dipertimbangkan secara seksama (anteseden) termasuk konsekuensi dari keputusan yang akan diambil dan bersifat strategis. Sedangkan kebijakan istilah dividen (dividen policy) adalah menyangkut keputusan manajemen tentang besar kecilnya dividen yang akan dibayarkan kepada pemegang saham.

Menurut Sartono (2000) kebijakan dividen adalah keputusan apakah laba yang diperoleh perusahaan akan dibagikan kepada pemegang saham sebagai dividen atau akan ditahan (retained earning) yang merupakan sumber dana internal guna pembiayaan investasi dimasa datang. Kebijakan dividen bersangkutan dengan penentuan pendapatan 
(earning) antara penggunaan pendapatan untuk dibayarkan kepada para pemegang saham sebagai dividen atau untuk digunakan didalam perusahaan yang berarti laba tersebut harus ditahan didalam perusahaan (Riyanto, 2008)

\subsection{Teori kebijakan dividen}

Menurut Brigham dan Houston (2010) menyebutkan ada tiga teori dari preferensi investor yaitu:

1. Teori Irelevansi Dividen (dividend irrelevance theory)

Teori yang menyatakan bahwa kebijakan dividen perusahaan tidak mempunyai pengaruh terhadap nilai perusahaan maupun biaya modalnya.

2. Teori The Bird-In-The-Hand

Bahwa sesungguhnya investor jauh lebih menghargai pendapatan yang diharapkan dari dividen daripada pendapatan yang diharapkan dari capital gain, karena komponen dividend yield, D1/P0, risikonya lebih kecil daripada komponen g dalam persamaan total required of return, $\mathrm{ks}=\mathrm{D} 1 / \mathrm{P} 0+\mathrm{g}$.

3. Teori Preferensi Pajak

Litzenberg menyatakan bahwa investor lebih menyukai laba ditahan dibandingkan dividen sebab preferensi pajak yang ditetapkan atas capital gain. Teori ini menyatakan bahwa perusahaan harus mempertahankan pembayaran dividen pada level rendah jika mereka ingin memaksimalkan harga saham.

Brigham dan Houston (2010) juga menambahkan dua isu teoritis lainnya tentang kebijakan dividen:

1. Hipotesis kandungan informasi atau pengisyaratan (information, or signaling content). Teori ini berdasarkan asumsi bahwa bahwa manajer mempunyai informasi yang lebih baik mengenai prospek masa depan dari pada pemegang saham. Teori ini yang menyatakan bahwa investor menganggap perubahan dividen sebagai isyarat dari prakiraan manajemen atas laba.

2. Pengaruh klientele (clientele effect). Teori ini menyatakan bahwa individual dan institusional yang membutuhkan current income akan berinvestasi di perusahaan yang memiliki pembayaran dividen tinggi. Pengaruh clientele menyatakan kecenderungan suatu perusahaan untuk menarik sekelompok investor yang menyukai kebijakan dividennya.

\subsection{Teori Keagenan (Agency Theory)}

Jensen dan Meckling (1976) menyatakan teori keagenan pada awalnya berkaitan dengan masalah kepemilikan perusahaan melalui pembelian saham. Pada perkembangannya, teori ini digunakan untuk menjelaskan hubungan antara dua 
pihak yang bersifat kontraktual (Eisenhardt,1989). Teori keagenan dalam manajemen keuangan membahas adanya hubungan agency dan principal (Jensen dan Meckling, 1976), yaitu hubungan mengenai adanya pemisahan antara kepemilikan dan pengelolaan yang dilakukan oleh manajer.

Sebagaimana dikemukakan oleh Crutchley dan Hansen (1989), hubungan keagenan yang terjadi karena adanya pemisahan antara kepemilikan dan pengelolaan manajer. Pemisahan tersebut terjadi karena pemilik modal melakukan diversifikasi portofolio dengan mendelegasikan kewenangan dan pengambilan keputusan kepada manajer dalam mengelola sejumlah dananya. Kontribusi teori keagenan mengingatkan pentingnya saling pengertian antara para pihak untuk berusaha mengurangi sifat mengutamakan kepentingan sendiri. Selain itu, juga mengingatkan pentingnya pengendalian diri dan harus menghilangkan kepentingan pribadi (self interest).

Hubungan keagenan muncul ketika satu individu atau lebih yang disebut pemilik (principal) mempekerjakan individu lain atau organisasi yang disebut agen untuk melaksanakan pekerjaan dan kemudian mendelegasikan otorisasi pengambilan keputusan kepada agen tersebut. Dalam konteks manajemen keuangan, hubungan keagenan yang utama adalah: (a) antara pemegang saham dan manajer, dan (b) antara manajer dan pemberi kredit.

\subsection{Konflik Keagenan (Agency Conflict)}

Myers (1977), hubungan keagenan merupakan hubungan yang rawan konflik, yaitu konflik kepentingan (agency conflict). Konflik tersebut terjadi karena pemilik modal selalu berusaha menggunakan dana sebaik-baiknya dengan risiko sekecil mungkin, sedangkan manajer (agent) cenderung mengambil keputusan pengelolaan dana untuk memaksimalkan keuntungan yang sering bertentangan dan cenderung mengutamakan kepentingannya sendiri. Principal menunjuk agen sebagai pihak pengelola dan pengambil keputusan bagi perusahaan dimaksudkan agar manajer mampu memaksimalkan kemakmuran pemilik atau pemegang saham. Namun dalam realitanya banyak terjadi "agency problem", yaitu konflik kepentingan antara manajer dan pemegang saham.

Brigham dan Houston (2010) menyatakan masalah keagenan (agency problem) yang potensial ini muncul ketika manajer perusahaan memiliki kurang dari 100 persen saham perusahaan. Masalah keagenan (agency problem) yaitu konflik kepentingan yang potensial antara agen (manajer) dan pemegang saham pihak luar atau pemberi hutang (kreditur). Konflik keagenan juga terjadi antara kreditur dan pemegang saham. 


\subsection{Biaya Keagenan (Agency Cost)}

Dalam konteks Agency Cost Model yang dikembangkan oleh Jensen dan Meckling (1976), kebijakan dividen digunakan untuk meminimalisasi agency cost yang timbul dari potensi conflict of interest antara agen (manajer) dengan principal (pemegang saham) akibat adanya pemisahan diantara kedua belah pihak tersebut. Agency cost merupakan biaya yang timbul dalam rangka mengendalikan atau mengawasi tindakan manajer agar sesuai kepentingan principal. Biaya keagenan yang meliputi monitoring cost adalah biaya yang timbul dan ditanggung prinsipal untuk memonitor perilaku agen, sementara bounding cost merupakan biaya yang ditanggung oleh agen untuk menetapkan dan mematuhi mekanisme yang menjamin bahwa agen akan bertindak untuk kepentingan prinsipal. Sedangkan residual loss timbul dari kenyataan bahwa tindakan agen kadangkala berbeda dari tindakan yang memaksimumkan kepentingan prinsipal.

Dasar dari agency cost model ini adalah ketika manajer disadari bisa bertindak tidak sesuai dengan kepentingan investor/pemegang saham, maka pemegang saham menggunakan mekanisme tertentu untuk mengontrol tindakan manajer tersebut. Salah satu dari mekanisme ini adalah melalui pembayaran dividen dengan payout yang tinggi (Beiner, 2001). Namun, Easterbrook (1984) mengemukakan bahwa efektivitas dividen sebagai salah satu sarana monitoring bergantung pula pada keberadaan sarana-sarana monitoring lainnya, misalnya struktur kepemilikan dan struktur modal perusahaan.

\subsection{Free Cash Flow Terhadap Kebijakan Dividen}

Free cash flow hypothesis dari Jensen (1986) menyatakan antara lain keberadaan free cash flow di dalam perusahaan akan mendorong manajer untuk memanfaatkannya ke dalam proyek-proyek yang tidak efisien sehingga memperbesar kemungkinan terjadinya agency problems karena tindakan demikian bertentangan dengan kepentingan pemegang saham. Sementara eksplanasi dari agency cost model (Easterbrook, 1984) menyatakan bahwa dividen merupakan salah satu sarana untuk memperkecil agency problems/cost di mana semakin besar kemungkinan agency problems semakin besar pula dividen yang diperlukan untuk mengendalikannya.

Berdasarkan kedua proposisi di atas dapat disimpulkan bahwa semakin besar free cash flow yang ada dalam perusahaan semakin besar potensi agency problems yang ditimbulkan dan semakin besar pula dividen yang diperlukan untuk mengendalikannya. Dalam arti semakin besar porsi free cash flow yang harus didistribusikan sebagai dividen kepada pemegang saham guna memperkecil terjadinya agency problems yang timbul dari free cash flow, dan sebaliknya.

Penelitian dari Lang and Litzenberger (1986), Lie (2004), Fuller \& Thakor (2002), telah menghasilkan temuan yang konsisten dengan free cash flow hypothesis 
tersebut. Berdasarkan argumen tersebut, hipotesis pertama dapat dirumuskan sebagai berikut.

H1 : Aliran kas bebas (Free Cash Flow) berpengaruh positif terhadap kebijakan dividen

\subsection{Maturity Tehadap Kebijakan Dividen}

Perusahaan yang memasuki maturity phase (fase kedewasaan) umumnya ditandai dengan menurunnya peluang pertumbuhan/investasi yang menguntungkan (growth/

investment opportunities), menurunnya capital expenditure, dan dengan demikian juga ditandai oleh berkurangnya kebutuhan dana. Berkurangnya kebutuhan dana ini pada gilirannya akan mendorong kenaikan dividen. Sejalan dengan maturity hypothesis dari Grullon et al. (2002), naiknya dividen dalam hal ini bukan dimotivasi oleh keinginan manajer untuk memberikan sinyal tentang prospek kinerja perusahaan, sebagaimana dijelaskan oleh signaling model, melainkan oleh meningkatnya dana yang tidak diperlukan akibat berkurangnya kebutuhan dana pada fase kedewasaan. Sharma (2001), Jain et al. (2003), dan Bullan et al. (2003) menemukan perusahaan-perusahaan yang melakukan inisiasi dividen mengalami penurunan pertumbuhan profitabilias pasca inisiasi dividen yang mengindikasikan bahwa mereka memasuki fase kedewasaan. Berdasarkan argumen-argumen dan temuan empiris tersebut, hipotesis kedua dapat dirumuskan sebagai berikut.

$\mathrm{H} 2$ : Tingkat kedewasaan (maturity) berpengaruh negatif terhadap kebijakan dividen

\subsection{Struktur Modal (Capital Structure) terhadap Kebijakan Dividen}

Terkait dengan dengan struktur modal, perusahaan yang mempunyai ketergantungan terhadap dana eksternal (utang) yang tinggi maka akan mendapat pengawasan yang intensif dari pemberi dana terhadap kinerja manajemen guna pengamankan dana yang dipinjamkan dalam perusahaan (Sprenmann \& Gentenbein, 2001). Sementara Easterbrook (1984) dalam monitoring rationalnya mengatakan bahwa efektifitas dividen sebagai sarana monitoring tergantung dari sarana-saran lain seperti monitorng oleh kreditor.

Di samping itu juga ada kecenderungan bahwa capital structure yang diperoleh perusahaan berpengaruh negatif terhadap jumlah dividen yang dibayarkan. Alasannya adalah bahwa bagi perusahaan-perusahaan dengan tingkat leverage tinggi maka kebijakan dividend payout yang tinggi akan memperbesar beban tetap perusahaan dan mengarah ke kebangkrutan. Nuringsih (2005) mengatakan bahwa bila perusahaan mengalami keterbatasan laba ditahan, perusahaan akan memanfaatkan utang. Namun menurut Ismiyanti dan Hanafi (2003), bila terlalu besar dapat berdampak pada financial distress dan kebangkrutan. Temuan ini memperkuat penelitian yang dilakukan oleh 
Easterbook (1984), Rozeff (1992), Noronha, et al. (1996) dan didukung oleh Shama (2001) dan Join, et al. (2003). Berdasarkan argumen tersebut hipotesis ketiga dapat dirumuskan sebagai berikut:

H3 : Capital Structure berpengaruh negatif terhadap kebijakan dividen

\subsection{Struktur Kepemilikan (Ownership structure)) terhadap Kebijakan Dividen}

Jensen \& Meckling (1976) menyatakan bahwa semakin tinggi struktur kepemilikan dikuasai oleh insiders (manajemen) atau semakin kecil yang dikuasai oleh pihak outsiders maka semakin berkurang agency problems, karena semakin selarasnya antara kepentingan manajemen dengan kepentingan pemilik yang sebagian besar adalah manajemen sendiri. Dalam hal demikian semakin kecil ketergantungan kepada dividen sebagai mekanisme monitoring. Di samping itu, kehadiran largeblock shareholding seperti institutional shareholding yang memiliki kapasitas monitoring yang lebih efektif dibanding pemegang saham kecil dan tersebar (atomistic shereholder), juga akan memperkecil peranan dividen sebagai monitoring mechanism (Easterbrook, 1984). Penelitian Dewi (2008) menyatakan semakin tinggi kepemilikan saham institusional semakin rendah kebijakan dividennya. Berdasarkan argumen tersebut hipotesis keempat dapat dirumuskan sebagai berikut.

H4 : Struktur kepemilikan (Ownership Structure) berpengaruh positif terhadap kebijakan dividen

\section{METODE PENELITIAN}

\subsection{Populasi dan Sampel Penelitian}

Populasi dari penelitian ini adalah seluruh perusahaan yang listing di Bursa Efek Indonesia (BEI) dalam kurun waktu 2010 sampai 2013, yang sampai dengan tahun 2013 tercatat berjumlah 472 perusahaan (Indonesia Capital Market Directory, 2014). Sampel dalam penelitian ini diambil dengan teknik purposive sampling. Pada penelitian ini diperoleh 60 sampel yang memenuhi kriteria. Adapun kriteria yang digunakan dalam mengambil sampel dalam penelitian ini adalah: (1) Seluruh perusahaan yang listing di BEI (ICMD) kecuali perusahaan bidang keuangan yang memiliki laporan keuangan lengkap sesuai dengan informasi yang diperlukan. (2) Perusahaan tersebut membagikan dividen selama periode penelitian 2010-2013. (3) Perusahaan tersebut mempublikasikan laporan secara teratur sejak tahun 2010-2013.

\subsection{Variabel Penelitian dan Pengukuran}


Variabel penelitian dan indikator-indikator pengukuranya dapat disajikan dalam tabel berikut.

Tabel 1. Variabel Penelitian dan Indikatornya

\begin{tabular}{|c|c|c|c|c|}
\hline No & Variabel & $\begin{array}{c}\text { Variabel } \\
\text { Penelitian }\end{array}$ & Indikator & Formula \\
\hline 1 & Independen & Free cash flow & Cash balance & Kas, setara kas / total aset \\
\hline 2 & & Maturity & $\begin{array}{c}\text { Capital } \\
\text { Expenditure }\end{array}$ & Total aset / market value + liability \\
\hline 3 & & $\begin{array}{c}\text { Capital } \\
\text { strucuture }\end{array}$ & $\begin{array}{l}\text { Long term debt to } \\
\text { equity ratio }\end{array}$ & Long term debt / total equity \\
\hline 4 & & $\begin{array}{l}\text { Ownership } \\
\text { strucuture }\end{array}$ & $\begin{array}{l}\text { Institutional } \\
\text { holding }\end{array}$ & $\begin{array}{l}\text { Jumlah saham kepemilikan } \\
\text { institusional / jumlah keseluruhan } \\
\text { saham }\end{array}$ \\
\hline 5 & Dependen & Dividend policy & $\begin{array}{l}\text { Dividend payout } \\
\text { ratio }\end{array}$ & $\begin{array}{c}\text { Dividend per share / earning per } \\
\text { share }\end{array}$ \\
\hline
\end{tabular}

\subsection{Data Penelitian}

Data yang diperlukan dalam penelitian ini adalah data sekunder, yaitu data yang dikumpulkan dari berbagai pusat data yang ada. Data tersebut berupa data laporan keuangan tahunan periode 2010-2013 yang diperoleh dari Indonesia Capital Market Directory (ICMD) tahun 2014. Teknik pengumpulan data yang digunakan adalah teknik pooling data atau penggabungan data.

\subsection{Metode Analisis Data}

Metode analisis data yang digunakan dalam penelitian ini adalah model regresi berganda dengan menggunakan program SPSS. Analisis ini digunakan untuk mengetahui pengaruh variabel independen (X) dalam hal ini Free cash flow (X1), Maturity (X2), Capital structur (X3), dan Ownership structure (X4). Terhadap variabel dependen $(\mathrm{Y})$ yang dalam penelitian ini adalah kebijakan dividen yang diproksikan dengan dividend payout ratio dan untuk pengujian hipotesis.

\section{TEMUAN DAN PEMBAHASAN}

\subsection{Hasil Analisis Deskriptif Variabel}

Penelitian ini mencoba menguji sebuah model regresi mengenai pengaruh biaya agensi terhadap kebijakan dividen perusahaan. Untuk memberikan gambaran karakteristik data penelitian maka dilakukan analisis deskriptif data. Statistika deskriptif berupa nilai rata-rata, nilai maksimum, minimum serta standar deviasi. Tabel berikut ini 
menyajikan statistik deskriptif variabel free cash flow, maturity ratio, capital structure, shareholder ownership, dan DPR.

Tabel 2. Hasil Analisis Descriptive Variabel

\begin{tabular}{lcrrrrr}
\hline & N & Minimum & Maximum & \multicolumn{1}{c}{ Mean } & Std. Error & Std. Deviation \\
\hline DIVIDEND PAYOUT RATIO & 60 & 2,985 & 84,179 & 34,27164 & 2,419575 & 18,741945 \\
FREE CASH FLOW & 60 &, 012 & 8,745 & 1,27830 &, 291081 & 2,254700 \\
MATURITY RATIO & 60 &, 158 & 2,435 &, 66250 &, 057338 &, 444137 \\
CAPITAL STRUCTURE & 60 &, 016 & 1,218 &, 30862 &, 043011 &, 333164 \\
SHAREHOLDER OWNERSHIP & 60 & 21,330 & 95,650 & 57,42917 & 2,828173 & 21,906934 \\
Valid N (listwise) & 60 & & & & & \\
\hline
\end{tabular}

Berdasarkan Tabel 2 Variabel kebijakan dividen (Dividend payout ratio) memiliki rata-rata hitung (mean) sebesar 34,27 artinya rata-rata DPR selama periode 20S10-2013 sebesar 34,27 persen per tahun. Standar deviasi (simpangan baku) adalah 18,74 artinya selama 4 tahun pengamatan, DPR pada perusahaan yang terdaftar di Bursa Efek Indonesia menyimpang dari rata-ratanya sebesar 18,74 persen. DPR terendah (minimum) selama peride pengamatan yaitu 2,98 persen. DPR tertinggi (maksimim) selama periode pengamatan 84,17 persen.

Variabel free cash flow memiliki rata-rata hitung (mean) sebesar 1,278, artinya rata-rata free cash flow selama periode 2010-2013 sebesar 1,78 persen dari total aktiva per tahun. Standar deviasi (simpangan baku) free cash flow adalah 2,25 artinya selama 4 tahun pengamatan, free cash flow pada perusahaan yang terdaftar di Bursa Efek Indonesia menyimpang dari rata-ratanya sebesar 2,25 persen. Free cash flow terendah (minimum) selama peride pengamatan yaitu 0,012 persen dari total aktiva. Free cash flow tertinggi (maximum) selama periode pengamatan pengamatan 8,75 persen dari total aktiva.

Variabel maturity memiliki rata-rata hitung (mean) sebesar 0,66 artinya rata-rata maturity selama periode 2010-2013 sebesar 0,66 persen per tahun. Standar deviasi (simpangan baku) maturity adalah 0,44 artinya selama 4 tahun pengamatan, maturity pada perusahaan yang terdaftar di Bursa Efek Indonesia menyimpang dari rata-ratanya sebesar 0,44 persen. Maturity terendah (minimum) selama peride pengamatan yaitu 0,158 persen. Maturity tertinggi (maximum) selama periode pengamatan adalah 2,44 persen.

Variabel Capital structure memiliki rata-rata hitung (mean) sebesar 30,8 artinya rata-rata perusahaan sampel memiliki utang terhadap total aktiva (capital structure) selama periode 2010-2013 sebesar 30,8 persen per tahun. Standar deviasi (simpangan baku) capital structure adalah 33 artinya selama 4 tahun pengamatan, capital structure pada perusahaan yang terdaftar di Bursa Efek Indonesia menyimpang dari rata-ratanya sebesar 33 persen. Capital structure terendah (minimum) selama peride pengamatan yaitu 1,6 persen. Capital structure tertinggi (maximum) selama periode pengamatan pengamatan 1,21 persen. 
Variabel Ownership structure (institutional ownership) memiliki rata-rata hitung (mean) sebesar 66 artinya rata-rata besarnya kepemilikan institusional terhadap total kepemilikan perusahaan (institutional ownership) selama periode 2010-2013 sebesar 66 persen per tahun. Standar deviasi (simpangan baku) institutional ownership adalah 44 artinya selama 4 tahun pengamatan, institutional ownership pada perusahaan yang terdaftar di Bursa Efek Indonesia menyimpang dari rata-ratanya sebesar 44 persen. Institutional ownership terendah (minimum) selama peride pengamatan yaitu 15,8 persen. Institutional ownership tertinggi (maximum) selama periode pengamatan 24,4 persen.

\subsection{Hasil Uji Normalitas}

Uji normalitas bertujuan untuk menguji apakah dalam model regresi, variabel pengganggu atau residual memiliki distribusi normal. Tabel 3 tersebut menunjukkan hasil uji statistik non-parametrik Kolmogorov - Smirnov $(K-S)$ dapat dilihat bahwa nilai Kolmogorov - Smirnov sebesar 0,770 dan tidak signifikan pada 0,05 (karena $\mathrm{p}=$ 0,593 > $0,05)$, yang berarti residual terdistribusi normal, dengan demikian uji selanjutnya dapat diteruskan.

Tabel 3. Hasil Uji Normalitas dengan One-Sample Kolmogorov-Smirnov Test

\begin{tabular}{llr}
\hline & & Unstandardized Residual \\
\hline $\mathrm{N}$ & & 60 \\
\hline Normal & Mean &, 0000000 \\
Parameters $^{\mathrm{a}, \mathrm{b}}$ & Std. Deviation & 15,90084322 \\
& &, 099 \\
Most Extreme & Absolute &, 099 \\
Differences & Positive &,- 067 \\
& Negative &, 770 \\
Kolmogorov-Smirnov Z &, 593 \\
Asymp. Sig. (2-tailed) & \\
\hline a. Test distribution is Normal. & \\
b. Calculated from data. &
\end{tabular}

\subsection{Uji Asumsi Klasik}

Sebelum dilakukan pengujian hipotesis terlebih dahulu dilakukan uji asumsi klasik untuk pemenuhan syarat regresi. Uji klasik menurut Ghozali (2014) secara umum terdiri dari (a) Normalitas, salah satunya dengan uji Kolmogorof-Smirnov (KS) yang mana nilai Z-nya tidak signifikan; (b) Heteroskedastisitas, untuk mendeteksi apakah dalam model regresi terjadi ketidaksamaan varians dari residual satu pengamatan ke pengamatan yang lain (Ghozali, 2009). Jika varians dari residual satu pengamatan ke pengamatan lain tetap, maka disebut Homoskedastisitas dan jika berbeda disebut 
Heteroskedastisitas. Model regresi yang baik adalah yang homoskedastisitas atau tidak terjadi heteroskedastisitas, dimana hasil output SPSS dari variabel independenya tidak signifikan, (c) Multikolinieritas, untuk mendeteksi ada atau tidaknya multikolinieritas dapat dilihat dari tolerance value $>0,1$ dan variance inflation factor $(\mathrm{VIF})<10$, asumsi terpanuhi karena semua variabel nilai tolerance > 0,1 dan nilai VIF , 10; dan (d) Autokorelasi, untuk mendeteksi tidak adanya autokorelasi dapat dilihat dari pengujian two-tailed menghasilkan nilai DW-statitik yang berada pada rentang du hingga 4-du (nilai DW-kritik). Hasil uji asumsi klasik menunjukkan bahwa semua asumsi terpenuhi kecuali untuk autokorelasi yang menunjukkan terjadi autokorelasi positif dapat dilihat pada Tabel 4.

Tabel 4. Uji T Dan Uji Multikoliniaritas

\begin{tabular}{|c|c|c|c|c|c|c|c|c|}
\hline \multirow{2}{*}{\multicolumn{2}{|c|}{ Model }} & \multicolumn{2}{|c|}{$\begin{array}{l}\text { Unstandardized } \\
\text { Coefficients }\end{array}$} & \multirow{2}{*}{$\begin{array}{c}\begin{array}{c}\text { Standardized } \\
\text { Coefficients }\end{array} \\
\text { Beta } \\
\end{array}$} & \multirow[b]{2}{*}{$\mathrm{t}$} & \multirow[b]{2}{*}{ Sig. } & \multicolumn{2}{|c|}{$\begin{array}{l}\text { Collinearity } \\
\text { Statistics }\end{array}$} \\
\hline & & B & Std. Error & & & & Tolerance & VIF \\
\hline \multirow[t]{5}{*}{1} & (Constant) & 34,357 & 9,554 & & 3,596 & ,001 & & \\
\hline & $\begin{array}{l}\text { FREE CASH } \\
\text { FLOW }\end{array}$ & ,934 & 1,267 &, 112 & ,737 & ,464 & ,563 & 1,775 \\
\hline & $\begin{array}{l}\text { MATURITY } \\
\text { RATIO }\end{array}$ & $-7,927$ & 6,341 &,- 188 & $-1,250$ & ,217 & ,580 & 1,725 \\
\hline & $\begin{array}{l}\text { CAPITAL } \\
\text { STRUCTURE }\end{array}$ & $\begin{array}{r}- \\
20,663\end{array}$ & 7,037 &,- 367 & $-2,936$ & ,005 & ,836 & 1,196 \\
\hline & $\begin{array}{l}\text { SHAREHOLDER } \\
\text { OWNERSHIP }\end{array}$ & , 180 & , 119 & ,211 & 1,521 & ,134 & 682 & 1,466 \\
\hline
\end{tabular}

\subsection{Hasil Pengujian Hipotesis Penelitian}

Berdasarkan hasil pengujian hipotesis dengan analisi regresi sebagaimana disajikan dalam Tabel 4 di atas. Hasil analisis menunjukkan bahwa dari empat hipotesis tentang pengaruh antara variabel yang di uji, adalah variabel free cash flow, maturity, ownership structure secara terpisah tidak terbukti berpengaruh terhadap variabel kebijakan dividen, dan hanya variabel capital structure terbukti berpengaruh terhadap variabel kebijakan dividen. Bagian pembahasan ini dimaksudkan untuk memberikan makna dan eksplanasi terhadap temuan-temuan hasil analisis tersebut.

\subsection{Pembahasan}

\section{Pengaruh Free Cash Flow terhadap Dividend Initiation Policy}

Pada inti dari theory free cash flow oleh Jensen (1986) terdapat masalah keagenan (agency problem) antara para manajer dengan pemegang saham atas distribusi free cash flow yang dilakukan perusahaan. Dengan kata lain, free cash flow menuntut adanya biaya agensi yang tinggi karena diperlukan pengawasan terhadap free cash flow yang dikelola 
oleh perusahaan. Hal ini tidak akan terjadi jika free cash flow tersebut dibayarkan kepada pihak pemegang saham dalam bentuk dividen sehingga dapat menurunkan biaya agensi. Hal inilah yang dibuktikan oleh penelitian ini.

Hasil pengujian hipotesis satu pada Tabel 3 menunjukkan pada koefisien positif $(0,934)$ dan $\mathrm{t}$ signifikan pada $\mathrm{p}$-value di atas $0,05(\mathrm{p}=0,46)$ berarti hipotesis satu ditolak. Dengan kata lain bahwa variabel free cash flow tidak berpengaruh terhadap variabel kebijakan dividen, ini juga menunjukkan bahwa pembayaran dividen yang dilakukan perusahaan tidak tergantung dari besar kecilnya free cash flow tersedia di perusahaaan. Hal ini juga membuktikan bahwa perusahaan membayar dividen bukanlah dimotivasi oleh keberadaan free cash flow, sebagaimana ditemukan di perusahaan-perusahaan di Amerika yang tingka kedewasaan (maturity). Dengan demikian temuan ini bertolak belakang dengan eksplanasi dari agency cost model khususnya free cash flow proposition dari Jehnsen dan Meckling (1986) termasuk temuan-temuan sebelumnya yang mendukung proposisi tersebut, seperti Jain et al. (2003) dan Sharma (2001) dalam hal kebijakan dividen Fuller \& Thakor (2002) dan Mollah, Kevin, and Short (2000).

Ada beberapa alternatif yang bisa menjelaskan hasil hipotesis Free cash flow tidak berpengaruh terhadap dividend policy sesuai dengan prediksi teori. Pertama Sugeng,B (2009) mengatakan terdapat temuan-temuan hasil pengujian hipotesis sebelumnya membuktikan bahwa sebagian perusahaan-perusahaan go-public di Indonesia berusaha keras bahkan ada kesan dipaksakan bahwa keputusan pembayaran dividennya sebagai sarana guna menimbulkan kesan yang menguntungkan di mata investor. Argumen di atas masuk akal seperti bahwa pengumuman perubahan pembayaran dividen bisa diterima mengingat fungsi strategis berupa indikasi awal bagi investor dalam menilai prospek kinerja perusahaan ke depan seperti diisyaratkan dalam signaling model, walaupun akibat keputusan manajer tersebut menjadikan kebijakan dividennya tidak kredibel dari perspektif signaling model.

Kedua faktor struktur kepemilikan dari perusahaan-perusahaan go-public di Indonesia yang didominasi oleh institutional holding (mayoritas dimiliki kelurga) yang pada umumnya tidak independen dengan pihak manajemen (Sugeng, 2009), dimungkinkan juga berperan dalam menjelaskan temuan di atas. Struktur kepemilikan yang demikian menyebabkan agency problem antara manajemen dan pihak pemegang saham di luar perusahaan menjadi relatif sangat kecil atau bahkan nihil. Terkait dengan kondisi obyektif struktur kepemilikan tersebut menyebabkan isu tentang free cash flow sebagai salah satu determinan dari agency cost model of dividend tidak relevan dalam pengambilan kebijakan dividen.

\section{Pengaruh Maturity terhadap Dividend Policy}

Hipotesis yang diuji dalam penelitian ini yang menyatakan bahwa variabel maturity berpengaruh terhadap dividend policy ini dikembangkan berdasarkan maturity 
proposition yang dikemukakan oleh Grullon, et al. (2002) sebagai eksplanasi alternatif terhadap signaling model.

Proposisi tersebut menyatakan bahwa kenaikan dividen yang direaksi positif oleh pasar bukan disebabkan oleh adanya persepsi dari pasar tentang prospek kinerja perusahaan yang lebih baik di masa yang akan datang, sebagaimana diprediksi dalam signaling model, melainkan disebabkan perusahaan telah memasuki fase kedewasaan. Pada fase ini perusahaan tidak lagi membutuhkan dana untuk membiayai investasi, sehingga untuk menghindari kelebihan dana/kas perusahaan memilih untuk menaikkan dividennya Jensen (1986)

Hasil pengujian hipotesis dua menunjukkan pada koefisien negatif $(-7,927)$ dan $t$ signifikan pada $\mathrm{p}$-value di atas $0,05(\mathrm{p}=0,217)$ yang terdapat pada Tabel 4 maka hipotesis tidak diterima berpengaruh terhadap kebijakan dividen, yang berarti hipotesis tidak diterima, dan mempunyai arah hubungan (tanda koefisien) negatif. Ini berarti besar kecilnya kebijakan pembayaran dividen tidak dipengaruhi oleh tingkat kedewasaan. Bertolak belakang dengan hipotesis penelitian dan juga dengan sendirinya maturity proposition dari Grullon, et al. (2002) yang mengisyaratkan tanda koefisien positif.

Ada beberapa alternatif yang bisa menjelaskan hasil hipotesis maturity tidak berpengaruh terhadap dividend policy sesuai dengan prediksi teori. Perusahaan yang memiliki capital expenditure lebih besar (tingkat kedewasaan lebih rendah) tentunya memiliki ekspektasi tentang prospek kinerja yang lebih baik dan karenanya berpotensi dapat meningkatkan profitabilitas dimasa yang akan datang, dan mampu memperoleh jaminan mempertahankan pembayaran dividen. Argumen ini didasarkan pada asumsi bahwa manajer memiliki preferensi terhadap keberlanjutan dividen dalam rangka menjaga reputasi mereka di mata pemegang saham.

Kedua, keputusan perusahaan bersedia membayar dividen yang lebih besar memberikan sinyal kepada para investor tentang prospek perusahaan yang lebih baik ke depan. Sebaliknya bagi perusahaan dengan capital expenditure lebih kecil (tingkat kedewasaan lebih tinggi) akan memiliki prospek profitabilitas lebih kecil di masa yang akan datang. Oleh karena itu, perusahaan akan membayar dividen lebih kecil sesuai dengan trend profitabilitasnya tersebut.

Dengan demikian disimpulkan bahwa maturity proposition tidak berlaku bagi perusahaan-perusahaan di Indonesia yang bersedia membayar dividen lebih besar tidak berarti mereka lebih dewasa (mature) dibanding mereka yang membayar dividen lebih kecil, dan sebaliknya sesuai argumen dari maturity proposition, sebab yang terjadi justru sebaliknya. 


\section{Pengaruh Capital Structure terhadap Kebijkan Dividen}

Capital structure merupakan variabel yang menjelaskan seberapa besar dana yang digunakan perusahaan bersumber dari utang. Hipotesis yang menghubungkan capital struture berpengaruh negatif terhadap dividend policy dikembangkan berdasarkan eksplanasi dari agency cost model. Terutama diargumentasikan dalam proposisi monitoring mechanism dari Easterbook (1984), Rozeff (1992), Noronha (1996), didukung oleh Shama (2001) dan Join, et al. (2003) yang menyatakan semakin besar ketergantungan perusahaan dari dana utang (kreditur) semakin semakin intensif pengawasan oleh pemberi dana terhadap kinerja perusahaan, sehingga memperkecil potensi agency problem antara agen dengan pemegang saham.

Hasil pengujian hipotesis tiga pada Tabel 3 menunjukkan koefisien capital structure bernilai negatif $(-20,66)$ dan t signifikan pada $\mathrm{p}$-value sama $0,05(\mathrm{p}=0,05)$ yang terlihat pada Tabel 3, artinya capital structure berpengaruh negatif dan signifikan terhadap kebijakan dividen dan hipotesis tersebut diterima. Adanya kontrol oleh pihak kreditor terhadap kinerja perusahaan menjadikan manajer menggunakan utang pada tingkat yang lebih rendah untuk mengurangi kemungkinan terjadinya financial distress dan risiko kebangkrutan. Semakin menurunnya penggunakan utang tersebut akan berdampak pada agency cost of debt. Dengan demikian semakin besar ketergantungan pembiayaan perusahaan dari utang maka semakin kuat kontrol eksternal terhadap kinerja manajemen dan mengurangi agency cost, sehingga perusahaan cenderung membayar dividen lebih rendah. Hasil penelitian memperkuat penelitian yang dilakukan oleh Easterbook (1984), Rozeff (1992), Noronha (1996), didukung oleh Shama (2001) dan Join, et al (2003, dan oleh Ismiyanti dan Hanafi (2003), Nuringsih (2005), yang memberikan bukti empiris bahwa kebijakan utang memberi pengaruh negatif terhadap kebijakan dividen.

\section{Pengaruh Kepemilikan (Ownership structure) terhadap Kebijakan Dividen}

Hasil pengujian hipotesis empat pada pada Tabel 3 menunjukkan pada koefisien pasitif $(0,180)$ dan $\mathrm{t}$ signifikan pada $\mathrm{p}$-value di atas $0,05(\mathrm{p}=134)$ yang terlihat pada tabel 4 sehingga hipotesis empat ditolak. Dengan kata lain bahwa variabel institutional ownership (outsider's holding) tidak berpengaruh terhadap variabel kebijakan dividen mengindikasikan bahwa perusahaan dengan institutional ownership yang tinggi tidak terbukti secara meyakinkan berdampak pada pembayaran yang lebih rendah, karena mereka dapat menekan agency problem sesuai dengan argumen agency cost model dan sebaliknya (Sugeng, 2009). Hal ini dikarenakan investor institusional memiliki keinginan yang kadang berbeda dengan keinginan investor umum. Horizon investasi mereka secara umum berjangka panjang sehingga mereka lebih menyukai perusahaan yang menginvestasikan kembali labanya daripada perusahaan yang membayarkan sebagian besar labanya untuk dividen. 
Perilaku unik tersebut terkait dengan dengan outsider's holding sebagian besar dimiliki oleh institutional ownership yang dalam kenyataannya berbentuk holding company yang saling berafiliasi dimana shareholder sebagian besar dimiliki keluargakeluarga rata kepemilikan holding 57,5 persen dan holding tertinggi sampai 95,65 persen. Akibat besarnya kepemilikan pihak-pihak di luar perusahaan yang tidak independen (satu sama lain saling berafiliasi), maka kepemilikan institutional ownership yang merefleksikan dari pihak luar persahaan tidak mempunyai secara signifikan, dalam arti karena mereka dominan dan satu sama lain tidak independen termasuk dengan manajemen, maka pada hakekatnya satu.

Dengan kata lain tingginya institutional ownership (hasil penelitian ini sebesar 57,5 persen) yang dilakukan perusahaan memberi dampak pada rendahnya dividend payout (DPR) perusahaan. Hasil penelitian ini konsisten dengan penelitian yang dilakukan oleh Eaaterbook (1984) dan Mahmoud, Perry \& Rimby (1998) yang menyatakan bahwa institutional ownership akan dapat mempengaruhi manajemen sehingga dapat mengurangi agency cost, dan tidak perlu lagi membayarkan dividen yang besar. Hasil penelitian yang bahwa Ownership structure tidak berpengaruh terhadap dividend policy telah memperkuat penelitian yang dilakukan oleh Amidu dan Abor (2006), yang mengatakan bahwa Institutional Ownership secara parsial tidak berpengaruh terhadap kebijakan dividen.

\section{KESIMPULAN}

Variabel free cash flow tidak berpengaruh terhadap variabel kebijakan dividen. Hal ini dimungkinkan karena pembayaran dividen di perusahaan-perusahaan publik di Indonesia: (1) tidak dimotivasi olen keberadaan free cash flow melainkan bagaiamana perusahaan berusaha keras bahkan ada kesan dipaksakan, juga sebagai sarana memberikan kesan menguntungkan dimata investor; (2) bahwa perusahaaan-perusahan go publik di Indonesia didominasi institutional holding (diduga mayoritas keluarga) sehingga tidak independen dengan pihak manajemen dan pihak pemegang saham di luar perusahaan yang relatif kecil, dengan demikian institutional hoding adalah satu.

Variabel maturity tidak berpengaruh terhadap variabel kebijakan dividen. Ini dimungkinkan: (1) perusahaan yang capital expenditure yang lebih besar (tingkat kedewasaan lebih rendah) tentunya memiliki ekspektasi prospek kinerja lebih baik, profitable serta mampu memperoleh jaminan mempertahankan pembayaran dividen; (2) perusahaan yang bersedia membayar dividen yang lebih besar memberikan sinyal kepada investor tentang prospek perusahaan yang lebih baik ke depan. Dengan hasil penelitian ini tidak sesuai argumen dari maturity proposition yang disampaikan Sharma (2001), Join, et al. (2003), dan Bullan, et al. (2003).

Variabel Capital structure berpengaruh terhadap variabel kebijakan dividen. Dengan semakin besar ketergantungan pembiayaan perusahaan dari utang maka 
semakin kuat kontrol eksternal terhadap kinerja manajemen dan mengurangi agency cost, sehingga perusahaan cenderung membayar dividen lebih rendah dan sebaliknya. Hasil penelitian sesuai yang dilakukan oleh Easterbook (1984), Rozeff (1992), Noronha et al (1996), didukung oleh Shama (2001) dan Join et al (2003).

Variabel Ownership structure terbukti tidak berpengaruh terhadap variabel kebijakan dividen. Keunikan perusahaan-perusahaan go publik di Indonesia umumnya didominasi oleh institutional holding (diduga dimiliki keluarga-keluarga dan saling berafiliasi) yang tidak independen dengan pihak manajemen, menjadi penyebab potensi agency problem tidak signifikan, Sugeng (2009) diduga menjadi pemicu utama temuan tersebut.

Pada akhirnya penelitian ini mendapat bukti empiris tentang keberlakuan agency cost model dalam kebijakan dividen khususnya di lingkungan perusahaan-perusahaan di Indonesia. Pada prinsipnya agency cost model yang dikembangkan oleh Jensen \& Meckling (1976) menyatakan bahwa kebijakan dividen sebagai salah satu sarana mekanisme monitoring prilaku manajemen, guna meminimalisasi agency cost yang timbul dari potensi konflik anatar agent dengan principal. Namun seperti yang diargumentasikan oleh Easterbook (2004) menyatakan efektifitas kebijakan dividen juga tergantung dari sarana monitoring lain. Penelitian ini mengimplikasikan bahwa agency cost tidak sepenuhnya berlaku dalam mengungkapkan keunikan pelaku pasar modal di indonesia dari perspektif agency cost. Atas bukti ini pelaku pasar tidak perlu percaya bahwa kebijakan dividen merupakan satu-satunya indikasi (signaling) prospek perushaan masa depan. Bukti empiris ini sekaligus memperkuat argumen ekstrim dari Frankfutter \& Wood (1997) mengatakan bahwa tidak terdapat bukti mengenai sebuah model kebijakan dividen dapat berlaku untuk semua konteks (Sugeng, 2009).

\section{DAFTAR PUSTAKA}

Amidu, M., \& Abor, J. (2006). Determinants of Dividend Payout Ratio In Ghanna. Journal of Risk Finance, 7(2), 136-145.

Beiner, S. (2001). Theories and Determinants of Dividend Policy. Financial Management, 24, 51-81.

Bhattacharya, S. (1979). Imperfect Information, Dividend Policy, and the "Bird in the Hand" Fallacy. Bell Journal of Economics, 10, 259-270.

Bulan, L. T., Subramanian N. \& Tanlu, L. (2007). On the Timing of Dividend Initiation. Financial Management, 36(4), 31-65.

Dewi, C. S. (2008). Pengaruh Kepemilikan Manajerial, Kepemilikan Institusional, Kebijakan Utang dan Ukuran Perusahaan Terhadap Kebijakan Dividen. Jurnal Bisnis dan Akuntansi, 10(1), 47-58. 
Crutchley, C. E. \& Hansen, R. S. (1989). A Test of Agency Theory of Managerial Ownership, Corporate laverage, and Corporate Dividend. Financial Management, 18(4), 36-46.

Easterbrook, F. (1984). Two Agency Cost Explanations of Dividend. American Economic Review, 74, 650-659.

Eisenhardt, K. (1989). Agency Theory, Assessment and Review. Academy of Management Journal, 14, 57-74.

Ferdinand, A. (2004). Metode Penelitian Manajemen, Edisi 5, Semarang: Badan Penerbit Universitas Diponegoro.

Frankfurter, G. M. \& Wood, B. G. (1994). Dividend Policy Theories and Their Empirical Tests. Journal of Financial Education, 23, 16-32.

Frankfurter, G. M. \& Lane, R.W.. (1984). The Rationality of Dividends. International Review of Financial Analysis, 7, 115 - 130.

Fuller, Kathleen dan Anjan Thakor. (2002). Signaling, Free Cash Flow, and Nonmonotonic Dividends. Journal of Financial Economics, 60, 1-34.

Ghozali, I. (2014). Ekonometrika, Teori, Konsep dan Aplikasi dengan IBM SPSS, Semarang: Badan Penerbit Universitas Diponegoro.

Gombola, M. J. dan Liu, F. Y. (1993). Considering Dividend Stability in the Relation Between Dividend Yield and Stock Returns. The Journal of Financial Research, 16(2), 139-150.

Grullon, G., Michaely, R. \& Swaminathan, B. (2002). Are Dividend Change as A Sign of Firm Maturity? Journal of Business, 75(3), 387-424.

Brown, G. T. (1996). "Free Cash Flow Appraisal . . A A Better Way?" The Appraisal Journal, 64(2), 171-182.

Han, K. C, Lee, S. H. \& Suk, D. Y. (1999), Institutional Shareholders and Dividends. Journal of Financial and Strategic, 12(1), 53-62.

Ismiyanti, F., \& Hanafi, M. M.. (2003). Kepemilikan manajerial, Kepemilikan Institusional, Risiko, Kebijakan Utang, dan Kebijakan Dividen: Analisi Persamaan Simultan. Dalam Prosiding Simposium Nasional Akuntansi IV (pp. 260-277). Surabaya, Indonesia.

Jain, B. A., Shekhar, C. \& Torbey, V. (2003). Determinants of Dividend Initiation by IPO Issuing Firm. Journal of Bankinng and Finance, 23, 1-31.

Jensen, M. C. (1986). Agency Cost of Free Cash Flow, Corporate Finance, and Takeovers. American Economic Review, 76(2), 323-329. 
Jensen, M. C., \& Meckling. W. H. (1976). Theory of the Firm: Managerial behavior, Agency Cost and Ownership Structure. Journal of Financial Economics, 3, 305360 .

Kumar, P. \& Lee, B.-S. (2001). Discrete Dividend Policy with Permanent Earnings, Financial Management, 30(3), 55-76.

Lang, L. H. P. \& Litzenberger, R. H. (1986). Evidence on The Impact of the Agency Cost of Debt on Corporate, Debt Policy. Journal of Financial and Quantitative Analysis, 21, 131-144.

Lie, E. (2004). On the Timing of CEO Stock Option Awards. Management Science, $51(5), 802-812$.

Mahmoud, M. A., Perry, L. G., \& Rimby, J. N. (1998). The Impact of Ownership Structure on Corporate Debt Policy: A Time Series Cross-Sectional Analysis. The Financial Review, 33, 85-89.

Myers, S. C. (1977). Determinants of Corporate Borrowing. Journal of Financial Economics, 5(2), 261-297.

Miller, M. H., \& Modigliani, F. (1961). Dividend Policy, Growth, and the Valuation of Shares, Journal of Business, 34, 392-414.

Miller, M. H., \& Scholes, M. (1981). Dividend and Taxes: Some Empirical Evidence, Journal of Political Economy, 90, 22-45.

Miller, M. H., \& Rock, K. (1985). Dividend Policy under Asymmetric Information. The Journal of Finance, 40, 1031-1051.

Mollah, A. S.., Keasey, K. \& Short, H. (2000). The Influence of Agency Cost on Dividend Policy in Emerging Market: Evidence from the Dhaka Stock Exchange. The Financial Review, November, 523-547.

Noronha, G. M., Shome, D. K., \& Morgan, G. E. (1996). The Monitoring Rationale for Dividends and the Interaction of Capital structure and Dividend Decisions, Journal of Banking and Finance, 20(3), 439-454.

Nuringsih, K. (2005). Analisis Pengaruh Kepemilikan Manajerial, Kebijakan Utang, ROA, dan Ukuran Perusahaan Terhadap Kebijakan Dividen: Studi 1995-1995. Jurnal Akuntansi dan Keuangan Indonesia, 2(2), 103-123.

Putri, I. F. \& Nasir, M. (2006). Analisis Persamaan Simultan Kepemilikan Manajerial. Kepemilikan Institusional, Risisko dan Kebijakan Utang dan Kebijakan Dividen dalam Perspektif Teory Keagenen. Dalam Prosiding Simposium Nasional Akuntansi IX (pp. 1-25). Padang, Indonesia: Universitas Padang.

Riyanto, B. (2008). Dasar-dasar Pembelanjaan Perusahaaan (Ed. 8). Yogyakarta: BPFE. 
Rozeff, Michael. (1992). How Componies Set Their Dividend Payout Ratio. Dalam J. M. Sterm \& D. H. Chew (Eds.), The Revolution in Corporate Finance. Oxford: Wiley-Blackwell.

Sartono, R. A. (2000). Manajemen Keuangan (Ed. 3). Yogyakarta: BPFE.

Saxena, A. K. (1999). Determinants of Dividend Policy: Regulated Versus Unregulated Firms. Diakses dari http://www.westga.edu/ bquest/1999/payout.html.

Sharma, S. (2001). Do Dividend Initiation Signal Prosperity? Journal of Finance, 51, 136.

Sprenman, K. \& Gantenbein, P. (2001). Theories and Determinants of Dividend Policy. Financial Management 24, 51-81.

Sugeng, B. (2009). Pengaruh Struktur Kepemilikan dan Struktur Modal terhadap Kebijakan Inisiasi Dividen Di Indonesia. Jurnal Ekonomi Bisnis, 14(1), 37-48.

Sunarto. (2004). Analisis Pengaruh Kepemilikan Manajerial, Invesment Opportunity Set, Return On Asset, dan Debt To Equity Ratio atrhadap Dividen Payout Ratio. (Tesis Magister yang tidak dipublikasikan), Universitas Diponegoro, Indonesia. 